\title{
PERLUNYA REFORMASI PENDIDIKAN, PEMBELAJARAN, DAN TEKNOLOGI DI ERA PENGETAHUAN
}

\author{
Dede Nuraida
}

Universitas PGRI Ronggolawe Tuban

\begin{abstract}
ABSTRAK
Saat ini kita sudah memasuki abad 21 yang juga disebut sebagai era pengetahuan, era ini ditandai dengan berkembangnya ilmu pengetahuan dan teknologi yang sedemikian pesatnya. Perkembangan yang terjadi di era ini membawa konsekuensi kepada tuntutan Sumber Daya Manusia yang berkualitas, untuk itu maka reformasi pendidikan nampaknya tidak bisa ditawar lagi, karena hanya pendidkanlah yang bisa mempersiapkan manusia untuk kehidupan di masa depan. Reformasi pendidikan yang dikehendaki untuk menyiapkan manusia di era pengetahuan ini meliputi reformasi dalam aspek-aspek: Tujuan, jenis-jenis keterampilan \& cara mendapatkannya, proses pembelajaran dan teknologinya, serta strategi reformasi yang efektif. Dengan adanya reformasi pendidikan ini diharapkan dihasilkannya generasi-generasi muda yang siap menghadapi tantangan jaman.
\end{abstract}

Kata Kunci: Reformasi pendidikan, era pengetahuan, strategi reformasi.

\section{PENDAHULUAN}

Saat ini kita sudah memasuki abad ke 21 atau sering disebut millennium ke 3, di mana perkembangan ilmu pengetahuan dan teknologi sudah sedemikian pesatnya. Abad ke 21 ini ditandai juga dengan perubahan besar pada orientasi kerja bisnis, dari bisnis yang berorientasi pembangunan manufaktur kepada bisnis yang berorientasi pada jasa. Perubahan pada bidang bisnis ini berimbas kepada proses penyediaan sumber daya manusia (SDM), yang tentunya harus bisa menghadapi tantangan abad 21 yang merupakan era pengetahuan.

Terdapat perbedaan mendasar dalam hal pemroresan bahan baku antara era industry dengan era pengetahuan. Pada era industry proses manufaktur dan perakitan (assembling) dapat dialkukan oleh tenaga terampil yang mungkin pendidikannya rendah sampai sedang, sedangkan pada era pengetahuan, pemrosesan informasi harus dilakukan oleh tenaga yang berpengetahuan dan ahli di bidangnya atau mereka yang berpendidikan tinggi (Trilling \& Hood, 1999) . Hal ini berarti bahwa dalam era pengetahuan, pendidikan memegang peran sentral untuk menumbuhkan pengetahuan dan keterampilan, sehingga dapat menghasilkan sumber daya manusia yang sesuai dengan kebutuhan.

Untuk menyiapkan sumber daya manusia sesuai dengan tuntutan di era pengetahuan ini, maka reformasi pendidikan nampkanya tidak dapat ditawar lagi, harus segera dilakukan oleh setiap lembaga pendidikan. Yang menjadi pertanyaan adalah reformasi pendidikan yang bagaimanakah yang diperlukan untuk menghadapi tantangan di era pengetahuan ini? Sebagai arahan terhadap persoalan tersebut mungkin 6 pertanyaan dasar yang dikemukakan oleh Trilling \& Hood (1999) bisa menjadi arahan. Keenam pertanyaan tersebut adalah:

1) Apakah perubahan (dari era industry menjadi era pengetahuan) ini mengubah tujuan pendidikan tradisional yang telah ada di masyarakat?

2) Keterampilan-keterampilan hidup apa saja yang diperlukan agar bisa berhasil di era pengetahuan?

3) Apa yang perlu dipelajari untuk mendapatkan keterampilan-keterampilan tersebut?

4) Apakah pembelajaran pada era pengetahuan benar-benar seperti dalam prkatiknya?

5) Bagaimana kita sampai ke sana, strategi reformasi mana yang efektif?

6) Bagaimana kita dapat menerapkan teknologi pembelajaran dan belajar dengan sangat baik untuk mendukung alternative tersebut?

\section{A. TUJUAN PENDIDIKAN TRADISIONAL VS ERA PENGETAHUAN}

Pergeseran dari era industry menjadi era pengetahuan, tentu saja membawa konsekuensi terhadap berubahnya tujuan dari pendidikan, karena pada dasarnya pendidikan berfungsi untuk menyiapkan peserta didik bagi peranannya di masa yang akan datang. Jadi pendidikan harus bisa menyiapkan anak didik untuk menjawab semua persoalan-persoalan hidupnya sesuai dengan tantangan zaman.

Menurut Trilling \& Hood (1999) ada 4 alasan pentingnya pendidikan bagi masyarakat, yatu (1) pendidikan dapat memberikan kemampuan bagi setiap individu untuk memberikan kontribusinya 
bagi masyarakat (2) pendidikan berperan dalam mengembangkan bakat-bakat pribadi (3) pendidikan memberikan peran pada individu untuk memiliki tanggung jawab kemasyarakatan (4) melanjutkan tradisi.

Memasuki era pengetahuan, tanggapan untuk tujuan pendidikan tersebut berubah secara dramatis, seperti yang tercantum pada table 1 .

Tabel 1. Perubahan Tujuan Pendidikan

\begin{tabular}{|c|c|}
\hline Tujuan Tradisional & $\begin{array}{l}\text { Respons pada Era } \\
\text { Pengetahuan }\end{array}$ \\
\hline $\begin{array}{l}\text { Individu mampu } \\
\text { memberikan } \\
\text { kontribusinya pada } \\
\text { masyarakat }\end{array}$ & $\begin{array}{l}\text { Pekerjaan berbasis } \\
\text { pengetahuan, } \\
\text { partisipasi dalam } \\
\text { ekonomi global }\end{array}$ \\
\hline $\begin{array}{l}\text { Mengembangkan } \\
\text { bakat-bakat pribadi }\end{array}$ & $\begin{array}{l}\text { Mewujudkan potensi } \\
\text { melalui pengetahuan }\end{array}$ \\
\hline $\begin{array}{l}\text { Menunaikan } \\
\text { tanggung jawab } \\
\text { kemasyarakatan }\end{array}$ & $\begin{array}{l}\text { Terlibat dan } \\
\text { mengetahui proses } \\
\text { pengambilan } \\
\text { keputusan secara } \\
\text { demokratis }\end{array}$ \\
\hline Melanjutkan tradisi & $\begin{array}{l}\text { Membangun identitas } \\
\text { diri dan bersimpati } \\
\text { terhadap budaya } \\
\text { kemajemukan }\end{array}$ \\
\hline
\end{tabular}

Sumber: Trilling \& Hood (1999)

Dalam era pengetahuan ini, untuk dapat memberikan sumbangan terhadap masyarakat diperlukan sekumpulan keterampilan baru, keterampilan kerja pengetahuan. Ketika kita menerapkan keterampilan-keterampilan pada pekerjaan kita, berarti kita telah berpartisipasi dalam jaringan yang luas dan rumit dalam hubungan ekonomi global, informasi, teknologi, politik, social, dan ekologi. Kita perlu mempelajari cara-cara baru untuk hidup dan bekerja pada dunia yang sangat kompleks, dunia yang kaya teknologi dan informasi.

Sekarang ini semakin banyak keuntungan yang bisa kita peroleh dari peralatan pengetahuan seperti computer dan peralatan komunikasi. Peralatan-peralatan tersebut meningkatkan pengetahuan kita, pekerjaan kita, dan peran kita. Dengan akses yang lebih bebas terhadap masalah, fakta, opini dan percakapan yang luas melalui media elektronik dan internet, membawa kita, potensi kita untuk terlibat dan partisipasi dalam proses demokrasi. Pada saat yang bersamaan, kita menjadi konsumen yang cerdas untuk menyaring informasi, dan karena semakin sedikit kumpulan media komersial yang mengendalikan dan semakin banyak sumber informasi, kita harus bekerja lebih keras untuk membuat pilihan yang hati-hati dari menu media harian yang berlebihan dan mengggunakan penilaian yang kritis.

Peningkatan mobilitas seluruh dunia, imigrasi, dan pernikahan antar Negara, membawa masyarakat ke keragaman budaya. Dengan bercampurnya budaya antar etnis, mendorong sebagian masyarakat tetap mempertahankan tradisi. Dengan semakin tingginya kemajemukan ini, mendorong kita untuk belajar bertoleransi pada tradisi dan identitas lainnya.

Untuk mencapai tujuan pendidikan di era pengetahuan ini, kesulitan yang mungkin dihadapi adalah kemampuan teknis kita dan ketidak mampuan untuk mengubah kebiasaan, pemikiran, dan struktur social dengan cepat.

\section{B. KETERAMPILAN-KETERAMPILAN DI ERA PENGETAHUAN \\ Menurut Trilling \& Hood ada 7 keterampilan (7C) yang diperlukan di era pengetahuan yaitu:}

\section{Bertindak dan Berpikir Kritis}

Para pekerja ilmu pengetahuan dituntut dapat menyelesaikan berbagai masalah yang kompleks, dengan menggunakan perangkat baik tenaga manusia maupun peralatan elektronik. Para pekerja perlu menguasai teknik penelitian dan analisis hasilnya, menyusun pemecahan masalah dan tindakannya, mengatur pelaksanaan pemecahan masalah, menilai hasil, dan kemudian memperbaiki penyelesaian sebagai akibat dari perubahan kondisi. Kemampuan dalam mendesain proses, manajemen kualitas, dan metode penelitian akan menjadi penting. Data base informasi yang online, akses $e$ mail yang cepat, dan web merupakan peralatan yang akan membantu mendukung pekerjaan pengetahuan tepat waktu.

Di era di mana informasi sangat mudah untuk diperoleh, kemampuan berpikir kritis memang sangat dibutuhkan. Berpikir kritis merupakan suatu aktifitas kognitif yang berkaitan dengan penggunaan nalar. Menurut Scriven \& Paul (dalam sudaryanto, 2007), berpikir kritis sebagai proses dan kemampuan yang digunakan untuk memahami konsep, menerapkan, mensintesis, dan mengevaluasi informasi yang didapat atau informasi yang dihasilkan. Jadi berpikir kritis dapat berfungsi sebagai penyaring (filter) terhadap informasi yang keabsahannya masih perlu dipertanyakan, sehingga kita dapat menentukan sikap terhadap informasi yang kita peroleh.

\section{Kreativitas}

Kreativitas di era pengetahuan diartikan sebagai kemampuan menemukan pemecahan baru terhadap masalah lama, penemuan prinsip-prinsip baru dan penciptaan produk-produk baru, penciptaan cara-cara baru untuk mengkomunikasikan ide-ide baru, dan penemuan cara-cara kreatif untuk mengatur proses-proses yang rumit. 


\section{Bekerja Kolaboratif}

Teamwork menjadi satu-satunya cara untuk menyelesaikan permasalahan yang rumit atau menciptakan peralatan, pelayanan, dan produk yang rumit. Kemampuan koordinasi dan kerja sama, kompromi dan consensus, merupakan kecakapan yang penting di era pengetahuan ini. Seperti yang ditetapkan oleh UNESCO, dalam mempersiapkan pendidikan manusia di abad 21, salah satunya adalah peserta didik perlu dilatih untuk bekerja sama dengan orang lain (learning to live together).

\section{Pemahaman Lintas Budaya}

Pekerja di abad pengetahuan harus menyadari akan keragaman etnis, social, organisasional, politik, dan budaya. Pada masyarakat yang sangat beragam budayanya, pertumbuhan ekonomi global, dan model organisasi, kecakapan lintas budaya, akan menjadi sangat berharga.

\section{Berkomunikasi}

Pekerja ilmu pengetahuan perlu memiliki keahlian berkomunikasi yang efektif dengan berbagai media, misalnya laporan di media cetak, dokumen elektronik, artikel majalah, artikel $e$-zine, buku, e-book, iklan cetak, iklan TV, iklan web, telepon, fax, situs, e-mail, brosur, simulasi, data base, dan lain-lain. Para pekerja ilmu pengetahuan ini akan terus dihadapkan pada pemilihan media untuk komunikasi, yang tepat waktu dan tempat, serta sesuai dengan konsumen, agar komunikasi bisa efektif dan efisien.

\section{Menguasai Penggunaan Komputer}

Di era pengetahuan setiap orang dituntut menguasai computer. Fasilitas computer sebagai bagian perangkat jaringan informasi, menjadi mutlak diperlukan, karena hal ini akan sangat membantu penyelesaian pekerjaan.

\section{Berkarir dan Belajar Menempa Diri}

Meningkatnya lapangan kerja dan kontrak kerja, menuntut para pekerja bisa mengatur langkah karir serta terus meningkatkan kemampuan diri. Tuntutan pekerjaan untuk memiliki kemampuan yang tinggi, kemampuan mengatur diri untuk dapat menyelesaikan tugas dengan baik, merupakan karir penting serta menjadi proses belajar sepanjang waktu.

Tabel 2. Tujuh Keterampilan (7C) yang Diperlukan di Era Pengetahuan

\begin{tabular}{ll}
\hline \multicolumn{1}{c}{ Keterampilan } & Komponen keterampilan \\
\hline $\begin{array}{l}\text { Critical thinking } \\
\text { and doing } \\
\text { (bertindak dan } \\
\text { berpikir kritis) }\end{array}$ & $\begin{array}{l}\text { Memecahkan masalah, } \\
\text { maneliti, menganalisis, } \\
\text { mengelola proyek, dll }\end{array}$ \\
\hline $\begin{array}{l}\text { Creativity } \\
\text { (Kreativitas) }\end{array}$ & $\begin{array}{l}\text { Bekerja sama, } \\
\text { berkompromi, membangun } \\
\text { komunitas }\end{array}$ \\
\hline
\end{tabular}

\begin{tabular}{|c|c|}
\hline $\begin{array}{l}\text { Cross cultural } \\
\text { understanding } \\
\text { (pemahaman } \\
\text { lintas budaya) }\end{array}$ & $\begin{array}{lr}\text { Mendalami } & \text { berbagai } \\
\text { (budaya) } & \text { etnik, } \\
\text { mengetahui } & \text { dan } \\
\text { mengorganisasi } & \text { berbagai } \\
\text { budaya } & \\
\end{array}$ \\
\hline $\begin{array}{l}\text { Communication } \\
\text { (berkomunikasi) }\end{array}$ & $\begin{array}{l}\text { Menyampaikan pesan dan } \\
\text { menggunakan media } \\
\text { komunikasi secara efektif }\end{array}$ \\
\hline $\begin{array}{l}\text { Computing(meng } \\
\text { uasai penggunaan } \\
\text { computer) }\end{array}$ & $\begin{array}{l}\text { Mengefektifkan } \\
\text { penggunaan peralatan } \\
\text { pengetahuan dan informasi } \\
\text { elektronik }\end{array}$ \\
\hline $\begin{array}{lr}\text { Carrer } & \& \\
\text { Learning } & \text { Self- } \\
\text { reliance } & \\
\text { (berkarier } & \text { dan } \\
\text { belajar menempa } \\
\text { diri) }\end{array}$ & $\begin{array}{l}\text { Mengelola perubahan, } \\
\text { belajar sepanjang hayat, } \\
\text { dan melakukan redefinisi } \\
\text { karir }\end{array}$ \\
\hline
\end{tabular}

\section{BELAJAR UNTUK MEMPEROLEH KETERAMPILAN}

Untuk melihat hal-hal apa saja yang harus dipelajari untuk memperoleh keterampilan, maka kita harus meninjaunya melalui prinsip pembelajaran itu sendiri

\section{Kontekstual}

Pada era pengetahuan, belajar yang sifatnya kontekstual sangat berarti, karena dalam belajar kontekstual kondisi lingkungan benar-benar menjadi tempat belajar. Pada pembelajaran kontekstual apa yang dipelajari dikaitkan dengan kondisi nyata, sehingga pembelajaran menjadi bermakna. Karena permasalahannya terkait langsung dengan lingkungan nyata yang tentunya bervariasi, maka siswa menjadi memiliki kesempatan yang lebih luas untuk menemukan, mendesain proyek, dan konstruk, daneksplorasi, dan memecahkan masalah. Dari sini diharapakan siswa menjadi terlatih untuk memecahkan masalah yang dihadapinya dalam kehidupan.

\section{Konstruksi}

Arti penting dari belajar sebenarnya adalah bagaimana membangun mental, membentuk/mengasimilasi pengalaman baru, mengakomodasi perubahan pada mode mental yang sudah kita miliki seandainya menemukan sesuatu yang tidak cocok dengan model mental yang sudah terbentuk. Jadi dalam hal ini, siswa harus membangun sendiri pengetahuan di dalam benaknya, dan guru harus menciptakan kondisi bagi siswa agar proses konstruksinya dapat berjalan dengan baik. Ibaratnya guru memberi siswa anak tangga, sedangkan yang harus menaiki tangga tersebut untuk mencapai tujuannya adalah siswa sendiri (Nur, 2002 dalam Trianto 2007). 


\section{Kepedulian}

Pembelajaran pada era pengetahuan harus mengembangkan motivasi diri dan kepercayaan diri, agar pembelajar terbiasa dan tetap kreatif dalam memecahkan masalah yang sulit sekalipun (Covington, 1998 dalam Trilling \& Hood 1999). Hal ini didasari karena motivasi intrinsic sangat penting dalam suatu proses belajar. Belajar yang berbasis masalah dan proyek, dimana pembelajar akan mendefinisikan sendiri proyeknya dan menyusun criteria untuk mengevaluasi proyeknya, hal ini akan dapat mengembangkanm motivasi intrinsic. Latihan semacam ini dapat diperoleh bila pembelajar memiliki kepedulian terhadap lingkungannya.

\section{Kompetensi}

Hal lain yang perlu dikembangkan dalam pembelajaran adalah kompetensi atau kecakapan. Kecakapan yang harus dikuasai tidak hanya didasarkan pada intelegensi (IQ), tetapi juga intelegensi emosi (EQ), verbal, logika matematika, intelegensi komunikasi, dan intelegensi spiritual (SQ). Setiap proses pembelajaran perlu membelajarkan pembelajar untuk mengidentifikasi kecakapan dirinya.

\section{Komunitas}

Kecakapan yang diharapkan pada era pengetahuan sangat konsisten dengan cara belajar secara alami, memecahkan masalah, mengembangkan kemampuan diri untuk berpikir dan bertindak, sehingga apa yang dipelajari akan sesuai dengan masalah real yang dihadapai. Pembelajaran harus diatur seperti kondisi alami yang sebenarnya, di mana pada kenyataannya manusia sebagai mahluk social yang selalu berinteraksi dengan orang lain. Oleh karena itu proses pembelajaran harus diatur sedemikian rupa dalam bentuk komunitas.

\section{PROSES PEMBELAJARAN PADA ERA PENGETAHUAN}

Berdasarkan analisis para ahli, program pendidikan yang tampak berhasil dalam pengembangan keterampilan dalam era pengetahuan, berusaha mengintegrasikan alat-alat informasi dan pengetahuan untuk menghasilkan pengetahuan sehari-hari. Praktik pendidikan dan pembelajaran di era pengetahuan akan semakin tegas memposisikan siswa dan alat bantu pembelajaran. Lebih jelasnya kekhususan praktik-praktik tersebut adalah:

1) Kita melihat perubahan paradigm pada praktik pendidikan, di mana penemuan pengetahuan berdasarkan latihan, praktik, dan aturan-aturan serta prosedur-prosedur, sangat sesuai pada era industry. Sebaliknya pengetahuan melalui proyek dan permasalah, penelitian dan disain telah sesuai untuk era pengetahuan.

2) Kita melihat bagaimana sulinya untuk mencapai reformasi system ketika tarikan paradigm lama cenderung muncul kembali. Kegagalan perubahan akan menyebabkan kita kembali dalam kebiasaan lama pada era industry.

3) Walaupun kita menekankan pada sifat yang berlawanan, mungkin lebih akurat untuk melihat tiap pasangan sifat era industry dan era pengetahuan sebagai suatu kesatuan.

4) Praktik-praktik pengetahuan di era pengetahuan sesuai dengan teori modern tentang bagaimana kita belajar.

5).Sekilas terlihat praktik era pengetahuan sangat tergantung pada peralatan pengetahuan modern, untuk menjadi sangat berhasil. Walaupun teknologi informasi dan teknologi merupakan katalisator penting untuk menggerakkan kita pada metode pengetahuan di era pengetahuan, kita harus selalu ingat bahwa metode pembelajarn kita yang berperan mengatur anaknak kita ke dalam era pengetahuan berkecakapan tinggi.

6).Satu hal yang paling penting, paradigm baru untuk pengetahuan ini menghadirkan tantangan dan kesempatan yang besar untuk perkembangan professional. Dengan demikian perlu didefinisikan kembali profesi pengajaran dan peran guru dalam proses pengembangan pengetahuan.

Secara ringkas, perbandingan kondisi pendidikan dan pembelajarn pada era industry dan era pengetahuan ini dapat dilihat pada table 3, di bawah ini.

Tabel 3. Bentuk Pembelajaran pada Era Industri dan Era Pengetahuan

\begin{tabular}{|c|c|}
\hline Era Industri & Era Pengetahuan \\
\hline Guru sebagai pengarah & $\begin{array}{lr}\text { Guru sebagai fasilitator, } \\
\text { pembimbing, } \\
\text { konsultan }\end{array}$ \\
\hline $\begin{array}{l}\text { Belajar } \\
\text { kurikulum }\end{array}$ & Belajar diarahkan siswa \\
\hline $\begin{array}{l}\text { Belajar dijadwalkan } \\
\text { secara ketat dengan } \\
\text { waktu yang terbatas }\end{array}$ & $\begin{array}{lr}\text { Belajar secara } & \text { terbuka, } \\
\text { fleksibel, dan sesuai } \\
\text { dengan keperluan }\end{array}$ \\
\hline $\begin{array}{l}\text { Terutama berdasarkan } \\
\text { fakta }\end{array}$ & $\begin{array}{l}\text { Terutama berdasarkan } \\
\text { projek dan masalah }\end{array}$ \\
\hline Bersifat teoritik & $\begin{array}{l}\text { Dunia nyata, tindakan } \\
\text { nyata, dan refleksi }\end{array}$ \\
\hline $\begin{array}{l}\text { Pengulangan } \\
\text { latihan }\end{array}$ & $\begin{array}{l}\text { Penyelidikan dan } \\
\text { rancangan }\end{array}$ \\
\hline Aturan dan prosedur & Penemuan dan penciptaan \\
\hline Kompetitif & Kolaboratif \\
\hline Berfokus pada kelas & Berfokus pada masyarakat \\
\hline $\begin{array}{l}\text { Hasilnya ditentukan } \\
\text { sebelumnya }\end{array}$ & Hasilnya terbuka \\
\hline Mengikuti norma & $\begin{array}{l}\text { Keanekaragaman ya } \\
\text { kreatif }\end{array}$ \\
\hline $\begin{array}{l}\text { Komputer } \\
\text { objek belajar }\end{array}$ & 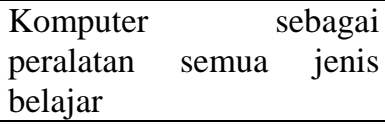 \\
\hline
\end{tabular}




\begin{tabular}{|c|c|c|}
\hline $\begin{array}{l}\text { Presentasi } \\
\text { media statis }\end{array}$ & dengan & $\begin{array}{l}\text { Interaksi multimedia yang } \\
\text { dinamis }\end{array}$ \\
\hline $\begin{array}{l}\text { Komunikasi } \\
\text { ruang kelas }\end{array}$ & sebatas & $\begin{array}{l}\text { Komunikasi tidak } \\
\text { terbatas, ke seluruh dunia }\end{array}$ \\
\hline $\begin{array}{l}\text { Tes diukur } \\
\text { norma }\end{array}$ & denagn & $\begin{array}{l}\text { Unjuk kerja diukur oleh } \\
\text { pakar, mentor, kawan } \\
\text { sebaya, dan diri sendiri }\end{array}$ \\
\hline
\end{tabular}

\section{E. STRATEGI REFORMASI YANG EFEKTIF DI ERA PENGETAHUAN}

Menurut Murphy (1990, dalam trilling \& Hood 1999) ada tiga pendekatan utama yang dapat digunakan untuk memperbaiki system pendidikan, yaitu: Model top down, bottom up, dan system mixed. Setiap pendekatan membawa beberapa tingkat keberhasilan untuk reformasi aspek tertentu dalam pendidikan.

\section{Strategi Top Down}

Pendekatan top down meruapakan pendekatan di mana perbaikan dilakukan dari tingkat atas ke tingkat bawah. Namun demikian sebaiknya tidak semua kebijakan ditentukan dari tingkat atas. Dengan pendekatan ini inisiatif pada tingkat nasional maupun local, dipusatkan pada standar materi, kurikulum, penilaian, pertanggungjawaban, penggajian, insentif, dan perubahan structural seperti pengurangan ukuran kelas.

\section{Strategi Bottom Up}

Pendekatan dari bawah ke atas, merupakan pendekatan di mana inovasi berasal dari bawah yang kemudian menentukan kebijakan tingkat atas. Pendekatan ini lebih tepat digunakan dalam mengembangkan proses pembelajaran. Inovasi kreatif yang dibawa oleh pengajar dan bahkan dari pelajar dipakai untuk memperbaiki model lama.

\section{Strategi Model Sistem Campuran}

Karena keterbatasan dari pendekatan bottom up dan top down, dilakukan usaha penggabungan dua model tersebut, yaitu model strategi reformasi sistematis (O'day \& Smith, 1993 dalam Trilling \& Hood, 1999). Model dari atas ke bawah mengajukan kepemimpinan dan dukungan untuk perkembangan dan koordinasi, inisiatif dari bawah ke atas memperoleh dukungan dan koordinasi dari atas ke bawah.

Dalam pendidikan bisa saja profil pengetahuan muncul dalam praktik yang dipelopori oleh guru, pelatih, guru dan siswa. Tuntutan keterampilan pada era pengetahuan sangat berbeda dari era sebelumnya. Macam peralatan ilmu pengetahuan juga semakin kuat dibandingkan dengan yang tersedia beberapa tahun sebelumnya.

Ketiga usaha di era pengetahuan, permintaan baru tentang keterampilan kerja ilmu pengetahuan, kemungkinan baru bahwa peralatan ilmu pengetahuan ditawarkan, dan pendukung cara- cara baru atas pengetahuan dari teori pengetahuan, semuanya bertemu pada model alternative baru dari pengetahuan dan pendidikan (Gambar 1).

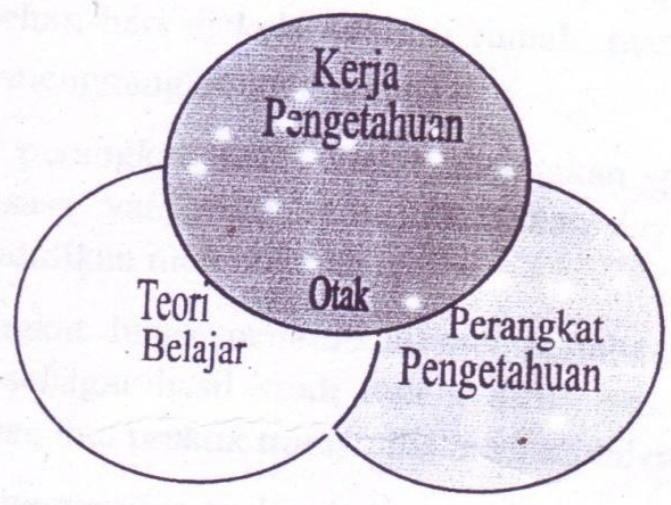

Gambar 1. Konvergensi Pembelajaran Era Pengetahuan

Sumber: Trilling \& Hood, 1999

Selain ketiga pendekatan utama yang sudah dijelaskan di atas, terdapat model alternative, yaitu

\section{Model Alternatif: Pusat Pembelajaran Masyarakat}

Berdasarkan kajian dari program-program peningkatan kualitas, kita dapat menentukan bentukbentuk dan trend baru untuk meningkatkan kualitas pembelajaran. Beberapa bentuk pusat pembelajaran tersebutadalah:

1) Kampus cangkokan (a hybrid campus); dibuka 6 hari dalam seminggu, dikelola secara non- profit dan profit-partnership dengan dunia paendidikan, kesehata, bisnis, dan pariwisata.

2) Pembelajaran kelompok kecil atau pembelajaran sebaya.

3) Kelas pembelajaran yang sarat aspek kehidupan.

4) Pembelajaran kecil dari berbagai kelompok umur.

5) Menggunakan sumber belajar yang beragam, seperti perpustakaan, museum, laboratorium, workshop, laboratorium music-tari-seni, kebun percobaan, dan ruang belajar bioekologi.

6) Pusat akses informasi yang dilengkapi dengan computer yang online dengan jaringan local, nasional, dan internasional.

Pusat kajian era pengetahuan ini akan meluas ke masyarakat dengan perhatian pada projek pelayanan masyarakat, praktik bisnis-mini. Masyarakat kampus merupakan prototype awal dari model ini. Kita dapat memulai mencermati bagaimana memahami strataegi reformasi yang akan membawa pada model alternative pendidikan baru. Strategi ini didasarkan pada 3 strategi penting yaitu: (1) meningkatkan 
kompetensi dalam pendidikan dan latihan (2) menurunkan biaya pendidikan dan penggunaan teknologi pendidikan (3) penggunaan secara efektif peforma dasar pendidikan praktis.

\section{F. TEKNOLOGI PEMBELAJARAN DI ERA PENGETAHUAN}

\section{Kendala Penggunaan Teknologi Pembelajaran}

Sehubungan dengan berkembangnya ilmu pengetahuan dan teknologi, tidak dapat dipungkiri bahwa proses pembelajaran harus melibatkan kemajuan teknologi dan informasi. Media pembelajaran yang biasa digunakan dalam proses pembelajaran selama ini, sedikit demi sedikit akan digantikan dengan media pembelajaran yang menerapkan teknologi tinggi.

Pada kenyataannya gap (jarak) antara teknologi pembelajaran yang harus kita gunakan dengan yang sesungguhnya digunakan sehari-hari di kelas dan di rumah, masih sangat jauh. Ada beberapa trend yang menjadi hambatan dalam penggunaan media ini, yaitu:

1) Perusahaan-perusahaan pembuat media (khususnya perangkat lunak) menggabungkan pendidikan menjadi pendidikan-hiburan raksasa yang sering membutuhkan investasi yang tinggi. Akibatnya perangkat pendidikan menjadi mahal.

2) Para pengembang perangkat lunak pendidikan mempertahanakan pengembangan model kurikulum baru, sebagai hasil studi dalam skala besar, sehingga system pengetahuan gaya pelatihan dan praktik tradisional menjadi hilang.

3) Web mulai terlihat lebih menyerupai mall pembelajaran yang besar.

4) Terlalu banyak dana dihabiskan untuk menghubungkan sekolah-sekolah, perpustakaan, sementara hanya sedikit yang diinvestasikan pada isi dan dukungan pengetahuan.

Saat ini sudah banyak multimedia, misal CDROOM yang dapat digunakan sebagai media pembelajaran, namun referensi media yang spesifik sesuai dengan bidang permasalahan masih sangat sedikit jumlahnya. Referensi multimedia yang difokuskan pada subjek ini, harus memberikan awal yang sederhana yang dapat membantu para peserta didik menemukan jawaban terhadap permasalahanpermasalahan yang ada.

Sumber-sumber referensi ini, tidak harus berupa fakta yang statis tetapi juga bisa menggunakan animasi simultan interaktif, untuk menjelaskan proses dan kedinamisan subjek dengan hubungan yang online pada masyarkat dan sumber-sumber ahli, sebagai bantuan dalam menemukan jawaban terhadap permasalahan yang lebih sulit.

2. Sepuluh Teratas (Top Ten) Tantangan Untuk Teknologi Pembelajaran

Menurut Trilling \& Hood (1999) ada 10 tantangan teknologi pembalajaran bagi para pengajar, ahli teknologi, pembuat kurikulum, pembuat dan pengembang program, penerbit materi pengetahuan, insinyur, ilmuan, pelatih, pengajar, orang tua, pelajar, dan wirausaha, yang ingin membuat kontribusi yang berharga bagi para pelajar dan pekerja, yaitu:

1) Kita memerlukan model program pengetahuan yang lebih efektif yang menyeimbangkan realita dan isi yang mendalam, yang mengkombinasikan secara efektif aktivitas tangan menggunakan kit, tantangan-tantangan desain, laboratorium penelitian dan eksplorasi dunia nyata.

2) Kita memerlukan situs referensi multimedia untuk belajar, yang mudah diakses, yang menampilkan simulasi interaktif, panduan komprehensif dan terbaru untuk dihubungkan dengan situs-situs web lainnya.

3) Kita memerlukan pembelajaran berkualitas tinggi, model simulasi belajar, dan alat-alat pembelajaran simulator pada proses yang rumit.

4) Kita memerlukan lompatan yang diinginkan pada kemudahan penggunaan dan hasil yang berguna dalam penemuan informasi, pengorganisasian dan pelaporan alat-alat, khususnya untuk web dan data base isi paengetahuan dan aktifitas pengetahuan.

5) Kita perlu untuk membuat pengembangan data base, pembagian dan proses pemeliharaan yang jauh lebih sederhana, sehingga kita kita dapat lebih mudah menciptakan dasar pengetahuan online yang baerguna.

6) Kita maemerlukan kolaborasi yang online dan alat komunikasi yang lebih baik.

7) Kita memerlukan system penilaian pengetahuan online yang berdasarkan 3R dan 7C yang menggabungkan simulasi, konsep pemetaan, pertanyaan-pertanyaan essay yang reflektif, presentasi portofolio, dan pelaporan hasil dari tugas pelaksanaan.

8) Kita memerlukan lebih banyak tempat untuk mendesain dan membuat alat, perkakas, dan barang-barang yang berguna, ruang kerja, laboratorium, garasi, dan sebagainya, dengan alat-alat material/bahan konstruksi, tempat penyimpanan alat, tempat yang aman untuk meletakkan barang secara bersamaan dan meletakannya secara terpisah, dan dengan akses tips konstruksi, online dan menunjukkan hasil temuan dan eksperimen siswa lainnya. 
9) Kita perlu melaksanakan semua bakat teknologi pendidikan kita, untuk tantangan mempersiapkan guru, orang tua, dan pemberi bantuan yang lain dan panduan belajar untuk menyatukan penggunaan semua jenis teknologi, dari lensa yang dimiliki ke super computer, ke dalam pengalaman sehari-hari semua siswa.

10) Kita perlu ke luar gedung, menarik nafas, berjalan-jalan, mencium harumnya bunga, dan melupakan teknologi setidaknya sehari sekali.

\section{KESIMPULAN}

Tuntutan keterampilan yang harus dimiliki oleh setiap orang di era pengetahuan seperti sekarang ini berbeda dengan era industry, oleh karena itu lembaga pendidikan selaku lembaga yang bertugas menyiapkan SDM untuk masa depan, sudah saatnya melakukan reformasi agar dapat menyiapkan generasi muda yang dapat menghadapi tantangan zaman.

Reformasi harus dilakukan secara menyeluruh, mulai dari tujuan, proses pembelajaran, system, serta media pembelajaran. Di era pengetahuan ini media pembelajaran sudah mengarah pada media dengan teknologi tinggi/modern, oleh karena itu guru yang memiliki fungsi sebagai fasilitator juga harus menguasai teknologi tersebut.

\section{DAFTAR PUSTAKA}

Atmadi, A \& Setiyaningsih, Y. 2000. Transformasi Pendidikan Memasuki Milenium Ketiga. Yogyakarta. Kanisius.

Sindhunata. Menggagas Paradigma Baru Pendidikan: Demokratisasi, Otonomi, Civil Society, Globalisasi. Yogyakarta. Kanisius.

Sudaryanto. 2007. Kemampuan Berpikir Kritis Sebagai Jalan Mencapai Kompetensi.(online).(http://www.fk.undip. ac.id/index.php?.option= com banners \& task $=$ click \& bid $=2$.

Tilaar, H.A.R. 2000. Paradigma Baru Pendidikan Nasional. Jakarta.Rineka Cipta.

Trianto. 2007. Model-model Pembelajaran Inovatif Berorientasi konstruktivistik: Konsep, Landasan teoritis-Praktis dan Implementasinya. Jakarta. Prestasi Pustaka.

Trilling, B \& Hood,P. 1999. Learning, Technology, and Education Reform in the Knowledge Age. Educational Technology/May-June 1999. 5:18. 